JEC

17,1

16

Received 10 March 2020 Revised 26 August 2020 27 December 2020

Accepted 4 February 2021

\section{How kinship resources alleviate structural disadvantage: self- employment duration among refugees and labor migrants}

\author{
Aliaksei Kazlou
}

Division of Business Administration, Linköping University, Linköping, Sweden and Division of Migration, Ethnicity and Society (REMESO), Linköping University, Linköping, Sweden, and

Karl Wennberg

Division of Business Administration, Linköping University, Linköping, Sweden

\begin{abstract}
Purpose - Economic integration of refugees remains a challenge for developed countries. Although refugees differ greatly from labor migrants in available resources and motivation toward self-employment, prevailing studies on minority and ethnic entrepreneurship tend to lump these different categories of migrants together. Based on theories of migrants' economic embeddedness, the purpose of this paper is to analyze the extent to which family- and kinship-based resources affect self-employment duration among refugees and labor migrants.

Design/methodology/approach - Based on Cox regression models, this longitudinal study estimates the self-employment duration of 10,519 refugees and 2,503 labor migrants starting businesses in Sweden in the period 2006-2012.

Findings - Results reveal that while refugees are at a disadvantage to labor migrants in terms of selfemployment duration, their higher level of family embeddedness in part helps them overcome these disadvantages. For refugees but not for labor migrants, co-location in an ethnic enclave also lowers the risk of them becoming unemployed after a spell in entrepreneurship.

Originality/value - This original paper provides empirical and theoretical contributions to research on migrants' self-employment success. It also discusses contributions for research on entrepreneurs' social embeddedness and refugees' entrepreneurship.
\end{abstract}

Keywords Refugees, Social embeddedness, Immigrant entrepreneurship, Labor migrants, Self-employment duration

Paper type Research paper

\section{Introduction}

Recent decades have seen increasingly large waves of uprooted individuals and families migrating across borders as refugees, with a need to establish themselves in a new country. At the same time, many host countries are increasingly open to migrating entrepreneurs

(C) Aliaksei Kazlou and Karl Wennberg. Published by Emerald Publishing Limited. This article is published under the Creative Commons Attribution (CC BY 4.0) licence. Anyone may reproduce, distribute, translate and create derivative works of this article (for both commercial and noncommercial purposes), subject to full attribution to the original publication and authors. The full terms of this licence maybe seen at http://creativecommons.org/licences/by/4.0/legalcode

The authors are grateful for financial support from FORMAS, grant 2018-02226. 
(Santamaria-Alvarez and Ś liwa, 2016). Although both labor migrants and refugees tend to be overrepresented in self-employment compared to natives, these two are unequally equipped in terms of preparedness for work in a new country, as well as the human, social and financial capital resources vital for entrepreneurship (Castles et al., 2013; Hammarstedt, 2001; Hjerm, 2004). This paper studies entrepreneurship among these two groups of immigrants in a highincome welfare state, Sweden, during its economic boom of 2005-2012. Although Swedish legislature at the time welcomed labor migrants moving for jobs or to create their own business, the same period also saw increasing rates of refugee migrants fleeing war and Refugees and labor migrants persecution. Both labor migrants and refugees tend to be overrepresented in self-employment compared to natives, yet we know little about their relative rates of economic disadvantage, to what extent these disadvantages affect their ability to sustain themselves in self-employment, and whether access to family- and kinship-based resources can affect their chances of selfemployment success. This motivates the following research question:

$R Q 1$. What resources influence the likelihood that refugees and labor migrants' remain in self-employment?

Although self-employment is frequently heralded as a potential path for economic integration among immigrants (Rath and Kloosterman, 2001), the conditions facing immigrants often put them at a disadvantage compared to natives when it comes to sustaining themselves (Joona, 2010; Sanders and Nee, 1996). Immigrants in general - and "forced" migrants like refugees in particular - often lack the human, financial and social capital resources needed to successfully establish and run a new business (Bates, 2011; Heilbrunn and Kushnirovich, 2007; Kushnirovich et al., 2017). Furthermore, it takes time to establish oneself in the host country, learn the language, establish local networks and adapt to the new culture and customs (Kossoudji, 1989).

Although there is a sizeable body of work on minority entrepreneurship (Aliaga-Isla and Rialp, 2013; Basu and Goswami, 1999; Bates, 2011; Dana, 2007 for recent reviews), this literature has, broadly speaking, tended to examine specific groups of migrants or compare the conditions of migrants against native entrepreneurship. There is little research that compares the relative disadvantages within different groups of migrants, despite the obvious heterogeneity between those migrating voluntary to a new country for work and those migrating due to conflict and persecution (Collier, 2013; Richmond, 1988). In this paper, we thus examine the relative disadvantages facing the full population of selfemployed labor migrants and refugees in Sweden during the period 2005-2012. We define "entrepreneurship" and "self-employment" within the broader pattern of "everyday entrepreneurship," which may or may not include innovative elements during inception or later on (Welter et al., 2017) [1]. We focus on labor migrants and refugees, as they represent two distinct root causes of migration while facing different types of conditions, which may put them at a disadvantage in entrepreneurship for different reasons. Refugees could be expected to be at a general disadvantage to labor migrants in terms of available resources (Chiswick et al., 2005) and psychological resilience after extended periods of hardship and flight (Bhugra, 2004; Shepherd et al., 2020), whereas labor migrants more often migrate on their own without family members (Taylor, 1999) and may thus lack some of the social support structures useful for entrepreneurial success (Kim et al., 2013).

Family support is vital for entrepreneurs for a number of reasons, including access to unpaid family labor (Dahl and Sorenson, 2009; Sanders and Nee, 1996), informal advice and emotional support (Kim et al., 2013) and access to financial capital during the start-up stage of a new venture (Light and Rosenstein, 1995). Hence, while we know little about the relative rates of disadvantage in entrepreneurship between refugees and labor migrants, theoretical 
arguments suggest that those disadvantages could be partly alleviated with access to family- and kinship-based resources.

In what follows, we draw on (Portes, 1995a, 1995b) theory of kinship-based resources and related research to theorize on three generic forms of family-based capital resources (financial, human and entrepreneurial capital) (Davidsson and Honig, 2003) and the indirect access to such resources through kinship-based local networks (Aldrich and Waldinger, 1990; Andersson and Hammarstedt, 2015) and their role for successfully sustaining oneself in self-employment. We derive four broadly testable hypotheses from the theory. We then describe the data used to test these hypotheses, which is based on the complete population of labor immigrants and refugees in Sweden that entered self-employment in the period 20062012. This rich micro-level data allows us to control for a range of individual- and macrolevel factors while at the same time create measures to test our theoretical arguments of family-based capital resources and local kinship-based networks. Duration models (Cox regression) are used to assess the likelihood of exit from self-employment at each time-point up to their first seven years in business. We find that the family's financial and entrepreneurial capital both decrease the likelihood of exit from self-employment for both refugees and labor migrants. However, a higher level of family human capital increases the likelihood of exit from self-employment among refugees (but not labor migrants). Although we find no general effects of regional ethnic capital [2] for labor migrant's likelihood of exit from self-employment, post hoc studies distinguishing between exit to unemployment and exit to paid employment reveal a strong negative effect of ethnic capital on the likelihood of refugee entrepreneurs becoming unemployed after closing their business. This indicates that for the most vulnerable types of migrant entrepreneurs - those who can come as refugees and subsequently seek to make a living by starting a new venture - residing in an ethnic enclave does in fact bring tangible benefits (Bates, 2011).

Our study provides several theoretical and empirical contributions to entrepreneurship research, specifically the literature on immigrant entrepreneurship and entrepreneurs' social embeddedness. First, we contribute to research on migrant self-employment success by comparing two large groups of migrants that are often lumped together. We show that not only do their relative rates of disadvantage differ in terms of likelihood of sustaining themselves as self-employed entrepreneurs, but also that the different types of capital resources available in their families and ethnic kinship serve to mitigate these disadvantages in distinct ways, whereas labor migrants exhibit higher rates of selfemployment duration than do refugees, refugee entrepreneurs have on average larger households and also seem to benefit more strongly from the available capital resources in the household - financial, human and entrepreneurial capital. These results contribute theoretical insights about the contextual boundaries of Portes' (1995a, 1995b) theory of kinship-based resource provision, which to date has mainly been tested in the American setting on heterogeneous groups of migrants. Our paper also serves to moderate prevailing expectations that refugees are necessarily at an economic disadvantage compared to other groups of migrants, and pinpoint what makes certain refugee entrepreneurs relatively less at a disadvantage than others. Second, the study is, to the best of our knowledge, among the first to integrate insights from research on the economic embeddedness of migrants in economic sociology from its original context in the USA to the setting of a high-income European welfare state, where self-employment and conditions for self-employment success among migrants is a more recent source of academic research and public policy debate. Third, we study a complete population data where we follow all labor migrants and refugees engaging in self-employment in Sweden over a period of seven years, using a rich set of independent and control variables. Our results thus come with strong claims of external 
validity, and it should be possible to transpose, challenge and extend our conclusions to other countries where migration waves and rates of migrant self-employment have increased over the past few decades.

Next, the theoretical framework of the paper is presented, followed by a description of the dataset we rely on and an account of the methodology. After this follows the empirical analysis, followed by a discussion with implications for theory and practice. We conclude by highlighting the study's limitations and provide avenues for further research.

\section{Theory and hypotheses}

A sizeable research has been devoted to study the conditions facing immigrant entrepreneurs. Immigrants have been documented to often exhibit high entrepreneurial motivation but often low perceived feasibility of entrepreneurial success (Kushnirovich et al., 2017). This discrepancy can be explained by a majority of immigrants being at a business disadvantage, as their skills, education and work experience are valued less in the developed nations to which they migrate than in their home country (Sanders and Nee, 1996). Furthermore, the human and financial capital resources of labor migrants and refugees are likely to differ to the extent that the former are often better equipped in terms of preparedness for work in a new country, as they migrate due to an already existing job offer or bring with them capital necessary to set up and run a new business (Berg and Spehar, 2013; Emilsson, 2014).

However, we know little in terms of differences in various capital resources of labor migrants and refugees, and how these resources affect their likelihood of exiting from or remaining in self-employment. Labor migrants and refugees are equally at an "outsider" disadvantage in terms of integration into a new society with its cultural particularities, such as language and customs, which is important when it comes to successfully running a small firm (Hammarstedt, 2003; Portes and Sensenbrenner, 1993). Tenure in the host country is one such factor that may serve to alleviate the "outsider" disadvantage (Kossoudji, 1989). Labor migrants and refugee migrants differ crucially regarding the scope of their kinship networks and family situation, as the former are "pulled" for work reason (in our setting a formal work offer is needed for a visa to migrant) while the latter are "pushed" out of their home country context for reasons of famine, persecution, war, etc. This has implications for their life situations and for the type of resources they may be able to access, which motivates a comparative analysis of if and how their self-employment is facilitated by access to familyand ethnic kinship-based resources.

Prior research highlights the importance of immigrants' embeddedness within their kinship network to access the resources and social support needed to sustain themselves in self-employment (Bates, 2011; Ohlsson et al., 2012; Sanders and Nee, 1996). The theoretical premises for these arguments are rooted in social embeddedness theory, which argues that individuals' relationships are crucial for them to mobilize the resources necessary to support their economic endeavors (Granovetter, 1985).

Our paper focuses specifically on two specific types of network-based resources: those of the immediate household family and those embedded in local kinship networks. In what follows we outline the theoretical foundations of family-based resources and local kinship networks, and derive four specific hypotheses as to why these matter for immigrants' ability to successfully sustain themselves as self-employed entrepreneurs.

\section{Family capital resources and immigrants' self-employment duration}

Immigrants tend to be at a disadvantage in host countries' formal economies partly because they - at least initially - have weaker relations with broader society. Often, self-employed 
immigrants are known to rely on family and co-ethnics' relations and resources (Portes, 1995a, 1995b). The position of immigrants as "outsiders" is known to facilitate feelings of "bounded solidarity" between family members, making family members more committed to mutual well-being and success and to share the resources they may have at their disposal (Baccari-Jamoussi et al., 2017; Portes and Sensenbrenner, 1993).

Families provide both tangible and intangible resources to the self-employed, all of which constitute a "set of family resources" supporting immigrants' economic endeavors (Granovetter, 1985; Portes, 1995b). Intangible resources include access to information, knowledge and emotional support, whereas tangible resources include much-needed financial capital and unpaid family labor (Aldrich and Cliff, 2003; Bates, 2011; Ratten et al., 2017). Following central strands in entrepreneurship and family business research, we theorize on three sets of resource bases known to facilitate entrepreneurial duration: financial capital, human capital and entrepreneurial capital (Bird and Wennberg, 2016; Davidsson and Honig, 2003; Estrin et al., 2016).

Family financial capital. The Lack of access to financial resources - for example through credit markets - is often highlighted as a key disadvantage for immigrant entrepreneurs (Bates, 1997; Efendic et al., 2016). Financial capital among family members in the household constitutes an important alternative funding source for immigrant entrepreneurs who have no business history and have not yet established relationships with financial institutions (Bates, 1997, 2011). Family financial capital comprises all financial resources within a family (such as incomes of other family members) and that can be employed for short- or long-term entrepreneurial investments (Bates, 2011). Overall, immigrants have limited access to regular financial institutions than do natives, and for recently arriving immigrants without a history of work, refugee migrants are particularly excluded from financial markets (Bates et al., 2017). In such situations, family financial capital represents a source of crucial support to helps immigrant entrepreneurs sustain their businesses, particularly during the first years of operation (Aldrich and Kim, 2007; Light and Rosenstein, 1995). For labor migrants, but specifically more so for refugees, the lack of access to the financial capital needed to sustain themselves in the uncertain first years in entrepreneurship may thus in part be alleviated by drawing upon their family's financial resources. Therefore, we expect that higher incomes available from families will reduce the likelihood of immigrants exiting from entrepreneurship:

H1a. Higher family financial capital decreases immigrant entrepreneurs' likelihood of exiting self-employment.

Family human capital. Human capital in the form of education is a central factor for successful entrepreneurship (Unger et al., 2011), perhaps in particular for ethnic minorities (Bates, 1990). More time spent in education often produces greater literacy and financial acumen, as well as a cognitive resource base to better assess the viability of new ideas commonly initiated by early stage entrepreneurs (Shane, 2003). Higher levels of human capital also allow immigrants to better assess profitable market niches that may affect their exit likelihood and, ultimately, sustain themselves as self-employed entrepreneurs. Here, family members' human capital is important, as family members are often those with whom entrepreneurs first share their ideas and discuss entrepreneurial plans (Aldrich and Cliff, 2003). However, human capital in the form of formal education varies widely among immigrant families and family members. Although some may not have finished primary education yet seek to set up a business such as a grocery store in the host country to which they have located, others - including their immediate or extended family members - may have completed both secondary or tertiary education (Duvander, 2001). Given this 
heterogeneity of human capital, both within immigrants as a group and within their families, the average level of education within a family approximates the shared cognitive resources upon which self-employed immigrant entrepreneurs can draw upon. For those immigrants who start businesses and need access to additional human capital to handle bureaucracy, planning, accounting and similar tasks, access to highly educated family members constitutes an important informal resource. Based on these arguments, we predict the following hypothesis:

H1b. Higher family human capital decreases immigrant entrepreneurs' likelihood of exiting entrepreneurship.

Family entrepreneurial capital. Previous research has documented the value of entrepreneurial experience for subsequent entrepreneurial success (Cooper et al., 1994; Ucbasaran et al., 2009). Although that research focused predominantly on the individual level, a number of scholars have also documented the value of self-employed family members' experience for the success of those engaging in self-employed entrepreneurship (Özcan, 2011; Sanders and Nee, 1996). Family members with an entrepreneurial background are well placed to advise and provide suggestions, in particular among immigrant entrepreneurs where feelings of "we-ness" are common (Bird and Wennberg, 2016; Sanders and Nee, 1996). Consequently, we posit accumulated entrepreneurial knowledge in the family as a third source of family-based capital of value for immigrant entrepreneurs, and propose it as an important factor enhancing how long immigrants remain as self-employed:

H1c. Higher family entrepreneurial capital decreases immigrant entrepreneurs' likelihood of exiting entrepreneurship.

Co-ethnic regional embeddedness and how long immigrants remain in self-employment

Extant research in economics, sociology and entrepreneurship highlights the vital role of "ethnic enclaves" to foster informal contacts with co-ethnics and promote economic success (Lancee, 2012). Theoretically, proximity to co-ethnics is posited to facilitate a joint understanding of the challenges associated with living in a new host country and how to conduct business there (Portes, 1995a, 1995b). Kinship here denotes nuclear and extended family and ethnic relatedness, i.e. hailing from the same country region (Ertug et al., 2020). In the immigrant entrepreneurship literature, ethnicity-based networks and blood and marriage relations in the extended family are all conceived as operating through the "kinship logic" of bounded solidarity and economic interdependence (Verver and Koning, 2017). Bounded solidarity is believed to emerge "out of the situational reaction of a class of people faced with common adversities" (Portes and Sensenbrenner, 1993). The feeling of foreignness among immigrants often triggers a sentiment of "we-ness" among those facing the similar difficult situation of trying to adjust to the new circumstances of the host society while lacking important resources, facing discrimination in the host society, and having higher barriers to returning to their home country, factors contributing to a shared contextual understanding (Lancee, 2012). In this way, co-ethnic immigrants' exposure to a foreign country can activate trust and feelings of trust and a willingness to share resources and advice. Ethnic kinship within geographical proximity of ethnic peers allows entrepreneurs to more easily share financial and human resources (Andersson, 2020; Andersson and Hammarstedt, 2015), for example in the form of "rotating credit schemes" or informal loans frequent in ethnic communities (Aldrich and Waldinger, 1990). Co-ethnics in close geographical proximity to immigrant entrepreneurs are better positioned to help them 
JEC

17,1

22

and capitalize on co-ethnic resources beyond those contributed by immediate family members. For example, a recent study by Andersson et al. (2018) on self-employment entry among Middle Eastern immigrants in Sweden suggested that ethnic enclaves increase the likelihood of co-ethnic entrepreneurs entering self-employment. If resource-pooling among co-ethnics in geographic proximity supports self-employed immigrants, we would expect such communities to lower the risk of self-employed immigrants exiting their businesses compared to immigrants running businesses in areas where few co-ethnics reside. Based on these arguments, we therefore suggest the following hypothesis:

H2. A larger local community of co-ethnics decreases immigrant entrepreneurs' likelihood of exiting entrepreneurship.

\section{Methods and data}

Studying the relative duration of self-employment among different categories of migrants requires detailed data on national origin, reason for and timing of migration, and occupational activities in the arrival country (Joona, 2010). Further, longitudinal data on immigrant entrepreneurs, including their educational level and their families' characteristics are needed to probe our hypotheses how kinship resources may affect the economic disadvantage that migrants often might face in self-employment. We draw upon LISA, [3] a set of rich register-based data provided by Statistics Sweden, which comprises time-varying information on all residents of Sweden, including all migrants with residence permits. Our data thus represent a population study with high external validity. The data contain detailed individual information on the education and incomes of immigrants and their families as well as geographic information. We combine individual and family characteristics to create explanatory variables approximating the theoretically posed sources of family capital. Similar to survey-based research and other research based on detailed governmental databases, we rely on prior research to carefully select and define our variables below, and discuss their validity as proxies of the underlying theoretical factors or we seek to examine.

Sweden is one of the European countries with high immigration levels in the past few decades. Labor market difficulties have been shown to lead to high rates of entrepreneurship among immigrants in Sweden (Hammarstedt, 2004) and the country exhibits one of the lowest labor market participation rates for migrants in Europe. This makes Sweden a relevant context in which to study the long-term outcomes of entrepreneurship. Given the length of the study period, several institutional changes happened in Sweden during the period, such as migration policy change in 2008 easing entry for labor migrants to Sweden and the global economic crisis of 2008-2009. As the global economic crisis had very limited impact on Sweden except for an upsurge in unemployment during 2009, which we control for in the analyses [4], temporary institutional changes are unlikely to influence our results.

Our sample is drawn from all Swedish residents of working age (20-65) born outside of Sweden who entered full-time self-employment by starting their own firm at any time in the period 2006-2012. We define "immigrant entrepreneur" as someone who is full-time selfemployed [5] in his or her business (Joona, 2010). Immigrants in our study consist of labor migrants and refugees. Labor migrants are defined as those who move for employment (IOM, 2018; Marchand and Siegel, 2015), whereas refugees received refugees' rights in the country. Similar to Desai et al. (2020), we use the term refugee to denote "a displaced person, in that her or his movement was spurred primarily by push rather than pull factors." We considered only the first generation as immigrants since many children of refugees and 
labor migrants alike are born in the new country as naturalized citizens and by definition are not refugees nor labor migrants (Baycan et al., 2012).

We chose the period 2006-2012, as we need at least a one-year time gap for the most recent migrants arriving in 2005 to gauge their entrepreneurial activities, and we want to follow entrants for up to seven years to identify a common duration of self-employment (Van Praag, 2003; Kossoudji, 1989; Sandberg et al., 2019a, 2019b). Together, the time period provides us seven full years of self-employment activity, enough to gauge whether an individual is able to sustain themself in self-employment or only for a relatively short spell. labor migrants We used information on residence permits granted after migration to Sweden to identify refugees and labor immigrants. Refugees $(N=10,519)$ comprise the majority of our study population. Among the refugees sampled, most come from Bosnia $(8.3 \%)$, Lebanon $(7.5 \%)$, Serbia/Croatia (5.8\%), Syria (5.5\%), Turkey (3.3\%), Afghanistan (2.7\%) and Former Soviet Union (FSU) republics (i.e. outside of Russia) (2.5\%), however, there is also a fairly large group of stateless refugees originating from the Middle East. On average, the refugees in our sample have lived in Sweden for 14 years and are 39 years old, but our sample includes those who have lived in Sweden for up to 38 years, as well as those arriving in 2005. This large variance of time spent in Sweden allows us to investigate the relative effects of country tenure on migrants' likelihood of remaining in self-employment.

The population of labor migrants is comparatively smaller, comprising 2,503 individuals who, at some point between 2005 and 2012, entered self-employment. Although of comparable age to the population of refugees, labor migrants' countries of origin are quite distinct: Poland (37.2\%), Germany (10.5\%), Lithuania (7.3\%), the Netherlands (5.6\%), Great Britain $(5.6 \%)$, Turkey $(2.4 \%)$ and Romania $(2.1 \%)$, with a further $5 \%$ originating broadly from countries in the Middle East. However, the average tenure in Sweden is much shorter for our sample of labor migrants: 5 years on average, but this includes those with tenure in Sweden of up to 28 years, as well as those arriving in 2005. The difference in regions of origin and average tenure in Sweden provides an interesting case for our comparative study of the relative rates of disadvantage in self-employment among refugees and labor migrants, as well as how access to family- and kinship-based capital resources may potentially serve to alleviate any disadvantages.

\section{Dependent variable}

Our hypotheses seek to examine how family- and kinship-based resources at the nuclear family level and ethnic group level affect the likelihood of exit from self-employment among the two contrasting groups of migrants.

Exit from self-employment is our dependent variable. It is coded 1 if an individual exited self-employment in a given year, and 0 otherwise (Van Praag, 2003). It is computed by investigating year-to-year transitions in occupational classification among the entrepreneurs in the sample (Block and Sandner, 2009).

\section{Independent variables}

We create two groups of independent variables, based on family members in the focal individual's household and their ethnic kinship ancestry, to test our hypotheses. We consider three groups of resources within the family that prior research generally suggests as important for entrepreneurial success: financial capital, human capital and entrepreneurial capital (Bates, 1990, 1999; Davidsson and Honig, 2003). We define families as co-residing nuclear families linked by the social ties of spouses or by blood relationships. Our definition of families thus includes the nuclear family of parents and children, as well as older parents, uncles/aunts and cousins, if they reside in the same household (Levin and Trost, 1992). 
JEC

17,1

Defining families beyond the traditional nuclear family is especially relevant for migrant families (Granovetter, 1998; Sanders and Nee, 1996). First, we count the number of adult family members to gauge the type and level of family resources, which is also included as a control variable:

Number of adult family members living in same household is a continuous variable coded from the number of adult family members living in the same household. The larger the number of working-age family members, the more family resources are expected to be available for self-employed immigrants as family members can contribute with unpaid labor, free consultancy or financial resources. This variable is important, as immigrant families are often relatively scattered, meaning that married couples may reside in different countries for extended periods, and occasionally away from their children. This variable is further employed in the calculation of other variables defining family.

Family financial capital (m). Average family income serves as a proxy for the financial capital available within the family (Bird and Wennberg, 2016). The variable is described in the LISA database as "disposable family income," which is updated annually. Given its nonlinearity, we use the natural logarithm of family income.

Family human capital. This variable represents the human capital stock available within the family and is measured as the average number of years of education received within the family (Portes and Zhou, 1993).

Family entrepreneurial capital. The variable serves as a proxy for entrepreneurial knowledge within a family (Godesiabois, 2005; Ratten et al., 2017). We expect that family members share their entrepreneurial experience and knowledge by giving advice on doing business (Caputo and Dolinsky, 1998; Ruef, 2010). The variable is computed as the proportion of family members who were entrepreneurs during the study period.

Ethnic capital. We define ethnic capital as a form of social capital within an ethnic group (Portes, 1995a, 1995b). This concept denotes indirect access to co-ethnics' human, financial and entrepreneurial capital based on the ethnic social network within immigrant groups living in close proximity (Ndofor and Priem, 2011). We measure ethnic capital as the proportion of immigrants from the same country as a focal individual, computed as the proportion of individuals from the same country of origin residing in the same "small area for market statistics" (SAMS) [6] (Andersson et al., 2020; Efendic et al., 2016).

\section{Control variables}

We seek to control for the following central factors not relevant for our theoretical arguments but shown as important in previous studies of self-employment duration (Evans and Leighton, 1989; Nziramasanga and Lee, 2001; Van Praag, 2003), especially among immigrants (Bates, 1990, 1999; Joona, 2010; Schutjens et al., 2017).

Entrepreneur's age. Individual age is coded as a continuous variable of number of years. Age influences self-employment, both as a source of general human capital and by diminishing persistence in uncertain and strenuous endeavors (Kautonen et al., 2014).

Gender. This dichotomous variable is coded as 1 for women and 0 for men. Women have often been shown to be at a disadvantage in self-employment. In particular, women may have bounded access to resources and need to rely more on family resources to mitigate such a disadvantage (Caputo and Dolinsky, 1998).

Years of education is a continuous variable denoting the number of years in formal education. As a measure of general human capital, education has been shown to affect the duration of minorities in entrepreneurship (Bates, 1990). However, longer education also means higher opportunity costs, as if the firm is not doing well, higher educated individuals are often better positioned to find regular employment (Wennberg, 2009). 
Incorporation/sole proprietorship. The legal status is an important distinction here, as selfemployment in incorporated businesses means higher investment of capital and suggests stronger commitment to the firm (Kwon et al., 2013). In Sweden, incorporation imposes higher financial, legal and tax requirements on founders (Edmark and Gordon, 2013). A dichotomous variable is coded 1 for firms registered as privately held incorporations and 0 for sole proprietorships/partnerships.

Marital status. We control for marital status with a dummy variable coded 1 if one is married (or cohabiting with joint children) or 0 otherwise.

Number of children may influence entrepreneurial commitment (Aldrich and Cliff, 2003). We therefore control for number of children using a continuous variable showing the number of dependent children up to 17 years of age.

Years since immigration. This variable measures the number of years an individual has spent in the host country since arrival. The longer that immigrants spend in the country the more country-specific capital they acquire, including culture knowledge (Duvander, 2001) and local language (Dustmann, 1999), assimilation and experiences at labor market (Kossoudji, 1989) and building social and human capital within time (Sandberg et al., 2019a, 2019b), which are important assets when engaging in business activities.

Region of birth includes separate dummy variables for each region of immigrants' origin. Given the number of different countries of origin with highly unequal numbers of individuals, we control for region of birth using six different country groups: Europe, the Middle East, FSU, Asia outside the Middle East, USA-Canada-Australia as one group, and a baseline category for "Other regions."

Metropolitan region is a control variable to account for the level of urban agglomerations, known to often attract more immigrant entrepreneurs (Rath and Kloosterman, 2001). We control for the major metropolitan region of Sweden: Stockholm, Gothenburg and Malmö/ Lund. Together, these areas comprise over $40 \%$ of Swedish gross domestic product (GDP) and a predominant share of small business activity. Other regions comprise the baseline category.

Regional unemployment rate. To account for the regional unemployment level affecting both demands for small business services as well as the potential to exit to alternative employment (Joona, 2010), we control for the regional (municipality) unemployment rate using publicly available data from Statistics Sweden, updated annually.

Regional GDP. We control for the regional (municipality) level of GDP using publicly available data from Statistics Sweden, updated annually (Braunerhjelm and Carlsson, 1999).

Industry. As prior research suggests that migrants have different strategies in growing or stagnating industries (Kloosterman, 2010), we include dummy variables for the eight major industries based on the standardized two digit standardized industry code (SIC): "Information and Communication," "Construction," "Hotels and restaurants," "Transport and retail," "Business services," "Finance and real estate," "Health and education" and "Manufacturing, Agriculture and Other industries."

\section{Analytical strategy}

Similar to earlier studies of self-employment dynamics (Van Praag, 2003) and migrants' selfemployment (Bates, 1999), we use duration analysis to model how long migrants remain in self-employment. Specifically, we use the flexible Cox specification is used, which does not require specific assumptions with regards to the distribution of the hazard ratio $(H R)$ (Lancaster, 1992). Cox regression models time $(t)$ as a function of an underlying hazard $(h)$ and a set of exponentiated beta coefficients $\left(b_{i j}\right)$ and covariates $(x)$ for individual $i$ at year $j$. 
The baseline hazard $h$ corresponds to the case where all covariates $(x)$ equal 0 , and is shifted up or down proportionally with changes in the covariates:

$$
h(t)=h_{0}(t) \exp \left(b_{i j}\right)\left(x_{i j}\right) .
$$

The Cox duration regression is based on maximum-likelihood estimation and models the risk of an event (in our case, exit from self-employment) occurring at any point in time during the period of observation. For every time period, the likelihood of the event occurring is compared to the likelihood of a "non-event" (in this case, remaining in self-employment). The beta coefficients of the theoretically derived covariates represent factors that affect this likelihood regardless of when an event occurs, or even if the event does not occur and the individual remains in self-employment until the end of the observation period (right censoring). Following Frederiksen et al. (2016), we show all results as HR where a HR above/ below 1 indicates a corresponding increase/decrease in the likelihood that the exit from selfemployment will happen in a given year.

\section{Results}

We first present descriptive statistics in Table 1, which describes the sample of labor migrants and refugees in Sweden who entered self-employment at any time in the period 2005-2012, and then we discuss the results of the Cox regression model. Table 1 shows that only among our population of self-employed refugees (labor migrants), $22 \%(24 \%)$ are women and $23 \%$ of the self-employed refugees were married compared to $15 \%$ of labor migrants. On average, self-employed refugees had more children (1.2) compared to selfemployed labor migrants (0.8). However, refugees have significantly longer residency in Sweden (14 years on average) compared to labor migrants (5 years on average), indicating that our population of self-employed refugees may in fact be more culturally accustomed to the host country than our population of self-employed labor migrants. When it comes to industries of operation, $20 \%$ of self-employed refugees are active in the hotels and restaurant industry, compared to only $8 \%$ among labor migrants. This industry is frequently documented as attracting low-skilled self-employed migrants at an economic disadvantage (Efendic et al., 2016; Kloosterman, 2000). Self-employed labor migrants are instead more common in the construction industry $(23 \%)$ where only $3 \%$ of self-employed refugees work. The majority ( $87 \%$ of labor migrants and $91 \%$ of refugees) run their firms as sole proprietorships.

Figure 1 shows the overall duration of self-employment among all labor migrants and refugees in Sweden who entered self-employment at any time between 2005 and 2012. It is apparent that throughout the first seven years in business, labor migrants are more likely to remain self-employed. The difference between the two groups seems to dissipate after seven years in business, after which our sample is right-censored. Wilcoxon tests for equality of means in the two groups' duration show a clear difference ( $\chi^{2}$-value: $\left.32.03, p<0.001\right)$, confirming that, on average, labor migrants are more likely to remain in self-employment. This provides tentative evidence that labor migrants are relatively less at a disadvantage in self-employment compared to refugees.

Results of the Cox regressions for refugees and labor migrants are illustrated in Table 2. The regressions estimate the likelihood of migrants exiting from self-employment. In the regression outputs, all coefficients are displayed as HRs, which ease interpretation of these as marginal effects, and which we address for each hypothesis. An HR of 1.01 indicates that a one-unit increase in covariate $x$ increases the likelihood of the outcome variable (selfemployment exit) by $1 \%$, whereas 0.99 indicates that a one-unit increase in covariate $x$ decreases the likelihood of the outcome variable by 1\% (Frederiksen et al., 2016). 
Self-employment and family descriptives

Entry rate to self-employment*

Exit rate from self-employment ${ }^{\mathrm{a}}$

Number of family members

Independent variables

Ethnic capital

Family financial capital (Disposable Family Income in 100' Swedish Krona)

Family human capital (average family years of education)

Family entrepreneurial capital ( $\%$ entrepreneurs in the family)

Control variables

Entrepreneur's Age

Gender $($ Female $=1)$

Number of Children

Years since immigration

Individual years of education

Stockholm County $(0 / 1)$

Incorporation

Sole proprietorship

Married (0/1)

Control variables - industry

Information and communication

Construction

Hotels and restaurants

Transport and retail

Business services

Finance and real estate

Health and education

Manufacturing, agriculture and other

Control variables - region of birth

Europe (0/1)

Middle East (0/1)

Former Soviet Union (0/1)

Asia

USA-Canada-Australia

Other
Labor migrants Refugees

$N=2,503 \quad N=10,519$

$5.9 \%$

$6.2 \%$

$1.01(0.16)$

$4.9 \%$

$7.3 \%$

$1.09(0.36)$

$5.0 \%$

$2.5(2.86)$

$10.8(4.95)$

$2.3(1.52)$

$7.0 \%$

$2.7(2.31)$

$10.1(3.50)$

$1.9(1.39)$

$\begin{array}{ll}38.90(8.96) & 39.26(9.80) \\ 24.5 \% & 22.1 \% \\ 0.76(1.01) & 1.27(1.32) \\ 5.05(3.84) & 13.97(6.63) \\ 11.8(5.03) & 11.5(3.18) \\ 37.1 \% & 46.1 \% \\ 12.5 \% & 9.8 \% \\ 87.5 \% & 90.2 \% \\ 14.4 \% & 22.4 \%\end{array}$

$\begin{array}{rr}4.8 \% & 2.1 \% \\ 31.2 \% & 4.0 \% \\ 8.2 \% & 20.5 \% \\ 9.4 \% & 32.9 \% \\ 9.9 \% & 3.5 \% \\ 1.0 \% & 1.2 \% \\ 4.6 \% & 6.7 \% \\ 30.9 \% & 28.8 \%\end{array}$

$$
\begin{gathered}
81.9 \% \\
5.3 \% \\
2.7 \% \\
4.3 \% \\
2.5 \% \\
3.53 \%
\end{gathered}
$$

$63 \%$

$3.5 \%$

$6.2 \%$

$0 \%$

$7.8 \%$
Refugees and labor migrants

27

Notes: The table shows mean values and standard deviations in parentheses, and is based on mean values upon entry into entrepreneurship throughout the study period 2006-2012. *Entry rates are based on the full population of individuals, i.e. the 2,503 self-employed labor migrants represents a $5.85 \%$ entry rate out of a total number of 42,786 labor migrants in Sweden, and the 10,519 self-employed refugees represents a $4.86 \%$ entry rate out of a total number of 216,440 refugees in Sweden during the study period. ${ }^{\mathrm{a}}$ Exit rate is based on the average yearly exit rate throughout the study period

Our first theoretically motivated independent variable, "Family Financial Capital," is statistically significant for both refugees (HR: 0.933, $p<0.01$ ) and labor migrants (HR: 0.944, $p<0.01$ ). The results show that the higher family financial capital is, the lower likelihood that immigrant entrepreneurs exit from entrepreneurship, supporting H1a. This result supports the theoretical arguments on financial support from the family in terms of financial resource provision among self-employed migrants. As family financial capital is computed in log format, the HR of 93.3 and $94.4 \%$ is difficult to gauge in terms of marginal effects. We, therefore, 
JEC
17,1

28

Figure 1.

Duration of selfemployment among labor migrants and refugees in Sweden, 2006-2012

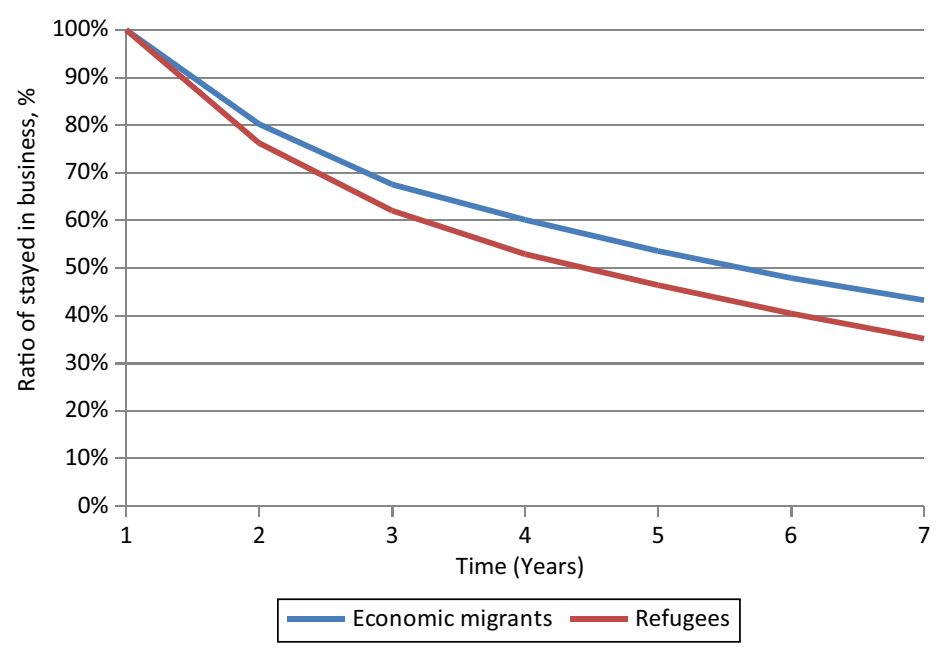

compute marginal effects by considering standard deviation and find that, on average, an increase of one standard deviation in family financial capital in our sample lowers the risk of exiting self-employment for refugees by $6.7 \%$ and for labor migrants by $5.6 \%$.

The second independent variable, "Family Human Capital," is statistically significant for refugees (HR: 1.038, $p<0.01$ ) but not statistically significant for labor migrants (HR: 1,015, $p>0.1)$. However, the HR is greater than 1 , meaning that each year of average education in a family increases the likelihood of exit by $3.8 \%$ for refugees. $H 1 b$ is thus not supported. Bearing in mind that refugees are overrepresented in low-skilled sectors (33 \% in retail and $20.5 \%$ in the hotel and restaurant industry), the higher exit for refugees with higher family human capital might mean that turning to regular employment is an alternative, which we ponder in the discussion section.

The third independent variable, "Family Entrepreneurial Capital," is statistically significant for both groups: HR: $0.433, p<0.01$ for refugees and HR: $0.372, p<0.01$ for labor migrants. The result supports our theory that entrepreneurial experience within a family is a strong factor in supporting entrepreneurial duration. As family entrepreneurial capital has a ratio between 0 and 1 , the $\mathrm{HR}$ of $43.3 \%(37.2 \%)$ implies that the difference between a refugee (labor migrant) entrepreneur without any family members experienced in entrepreneurship in Sweden and a refugee (labor migrant) entrepreneur with all family members having entrepreneurial experience is a $56.7 \%(62.8 \%)$ lower likelihood of exit for the latter.

Finally, our fourth independent variable, "Ethnic Capital," is not statistically significant in the regression estimates of the likelihood of self-employment exit for either refugees (HR: $0.785, p>0.10$ ) or labor migrants (HR: $0.738, p>0.10$ ) in the main analysis. The absence of significant effect of the ethnic capital independent variable might be related to its compound character, or the heterogeneity of migrant entrepreneurs' reasons of exiting their businesses (i.e. push or pull factors). Control for regional differences shows, that higher-level regional GDP tends to decrease the exit rate from entrepreneurship for both groups. In the robustness section that follows in Appendix, we therefore analyze separately the effect of all independent variables for the likelihood of exiting to unemployment or paid employment, among labor migrants and refugees, respectively. See correlation matrix for labor migrants Table A1 and refugees Table A2 in Appendix. 


\begin{tabular}{|c|c|c|c|}
\hline & Labor migrants & Refugees & \\
\hline \multicolumn{4}{|l|}{ Independent variables } \\
\hline Ethnic capital & $0.340(0.500)$ & $0.827(0.207)$ & \\
\hline Family financial capital (family disposable income (ln)) & $0.959 * *(0.0189)$ & $0.931^{* * * *}(0.00774)$ & \\
\hline $\begin{array}{l}\text { Family human capital (average family years of } \\
\text { education) }\end{array}$ & $1.027 * *(0.0124)$ & $1.042^{* * * *}(0.00558)$ & \\
\hline $\begin{array}{l}\text { Family entrepreneurial capital (average No. of } \\
\text { entrepreneurs in a family) }\end{array}$ & $0.367 * * *(0.0158)$ & $0.428 * * *(0.00763)$ & 29 \\
\hline \multicolumn{4}{|l|}{ Control variables - individual } \\
\hline Entrepreneur's age (years) & $0.991 * *(0.00430)$ & $0.987^{* * * *}(0.00148)$ & \\
\hline Gender $($ Female $=1)$ & $0.863 *(0.0759)$ & $0.960(0.0330)$ & \\
\hline Number of children & $0.908 * *(0.0343)$ & $1.017(0.0121)$ & \\
\hline Years since immigration & $0.989(0.00908)$ & $0.998(0.00242)$ & \\
\hline Years of education & $0.975 * *(0.0107)$ & $0.970 * * *(0.00565)$ & \\
\hline \multicolumn{4}{|l|}{ Control variables - industry } \\
\hline Information and communication & $0.703 * *(0.110)$ & $0.514 * * *(0.0592)$ & \\
\hline Construction & $0.268 * * *(0.0301)$ & $0.360 * * *(0.0356)$ & \\
\hline Hotels and restaurants & $0.629 * * *(0.0966)$ & $0.292 * * *(0.0156)$ & \\
\hline Transport and retail & $0.596 * * *(0.0776)$ & $0.327 * * *(0.0128)$ & \\
\hline Business services & $0.338 * * *(0.0591)$ & 0.656 **** $(0.0518)$ & \\
\hline Finance and real estate & $1.064(0.302)$ & $0.645 * * *(0.0831)$ & \\
\hline Health and education & $1.133(0.138)$ & $1.158 * * *(0.051)$ & \\
\hline \multicolumn{4}{|l|}{ Control variables - region of birth } \\
\hline Europe & $1.296 *(0.189)$ & $0.856 * * *(0.0511)$ & \\
\hline Middle East & $1.288(0.275)$ & $0.985(0.0524)$ & \\
\hline Former Soviet Union & $1.400(0.327)$ & $0.844 *(0.0814)$ & \\
\hline Asia & $1.083(0.226)$ & $1.052(0.0790)$ & \\
\hline \multicolumn{4}{|l|}{ Control variables - regional environment } \\
\hline Stockholm County $(0 / 1)$ & $0.361 * *(0.171)$ & $0.412^{* * * *}(0.0792)$ & \\
\hline Regional GDP (Swedish Län) & $0.995 *(0.00245)$ & $0.995 * * *(0.00100)$ & Table \\
\hline Regional level of unemployment & $1.067(0.0551)$ & $0.979(0.0189)$ & Results from cox \\
\hline Unique number of individuals & 2,503 & 10,519 & \\
\hline Exits & 915 & 5,256 & employment duratic \\
\hline Individual-year observations & 6,084 & 27,332 & employment auration \\
\hline Log Pseudo-likelihood & $-5,538.075$ & $-44,955.91$ & $\begin{array}{l}\text { among refugees and } \\
\text { labor migrants in }\end{array}$ \\
\hline Notes : ${ }^{*} p<0.1 ; * * p<0.05 ; * * * p<0.01$ & & & Sweden, 2005-2012 \\
\hline
\end{tabular}

\section{Robustness tests}

To account for the potential heterogeneity among immigrants exiting self-employment to take up a regular job or for some other reason, we conducted a series of robustness tests (see Appendix) where we distinguished between both labor migrants and refugees that exit to unemployment and those that exit to take up paid employment. Of the 915 labor migrants who exited self-employment, $548(60 \%)$ indeed exited to unemployment, whereas $367(40 \%)$ exited to paid employment, supporting our assumption in the main models that leaving entrepreneurship for this group is primarily involuntary. However, among the 5,256 refugees who exited self-employment, only $2,673(51 \%)$ did so to unemployment, whereas $2,583(49 \%)$ exited to paid employment. This highlights that the labor market opportunities for labor migrants and refugees differ and that, among the latter, self-employment may more 
often be a stepping-stone to the regular labor market. To ascertain the veracity of our hypothesized effects with regard to kinship resources, we also estimated Cox models separately for those that exit to unemployment vs those that exit to paid employment, for both labor migrants and refugees, respectively (Table A3). In Appendix our results regarding the role of family human capital $(H 1 b)$ and family entrepreneurial capital $(H 1 c)$ remained, by and large, the same. However, in these robustness tests the results for family financial capital $(H 1 a)$ were positively associated with exit to unemployment for both refugees and labor migrants, but negatively associated with exit to employment for both groups. This highlights the importance of further scrutinizing the role of access to financial capital at various stages of entrepreneurship among immigrant entrepreneurs (see Discussion and Conclusion).

Interestingly, the non-significant results for $H 2$ (the role of ethnic capital in the form of spatially proximate co-ethnics) remained the same for labor migrants in these robustness tests, but among refugees we observe a strong negative effect of ethnic capital on the likelihood of exiting to unemployment (refugees (HR: $0.343, p<0.01$ )), meaning that if the number of co-ethnics in the local SAMS region increases by $10 \%$, the likelihood of a focal entrepreneur from the same country or region exiting from self-employment decreases by about $6.7 \%$. This is a sizeable effect and could likely depend on co-ethnics being important for local businesses as customers, etc. (Bates, 2011).

\section{Discussion and conclusions}

In this study, we set out to examine the duration of self-employment among labor migrants and refugees in Sweden using a longitudinal design with a rich set of individual- and familylevel factors. Sweden illustrates a specific context as:

- a mature welfare state (Esping-Andersen, 1990);

- a state with relatively large refugee and labor migrant groups compared to most European countries (Hagelund, 2020); and

- one of the states was immigrants (both refugees and labor migrants) have relatively more marginalized in the labor market compared to natives (Backman et al., 2020).

Based on theories of migrant economic embeddedness in economic sociology, we theorized on different ways in which family- and kinship-based resources could affect selfemployment duration among refugees and labor migrants, deriving four hypotheses that we scrutinized using duration models.

We found that, while higher levels of both financial and entrepreneurial capital among household family members decrease the likelihood of exit from self-employment for both refugees and labor migrants, a higher level of family human capital increases the likelihood that self-employed refugees (but not labor migrants) will exit self-employment. As some prior research suggests that individual migrants' level of education is negatively associated with self-employment entry (Eriksson and Rataj, 2019; Hammarstedt, 2001), it may well be that family members with higher education could be in a position to help the rest of the family find employment instead of continuing in self-employment, which could serve to explain these results if self-employment is a forced rather than an active choice among refugees.

Supportive of such an interpretation, a prior study by Bird and Wennberg (2016) investigated formerly unemployed migrants (but failing to distinguish between categories of migrants) in Sweden between 2001 and 2006 but found no evidence of a relationship between family members' human capital and self-employed migrants' transition from 
self-employment to paid employment (Evansluong and Pasillas, 2017). These contrasting effects of kinship resources may be explained with the structural theory of kinship support (Ertug et al., 2020), as advice-giving and resource-pooling within extended families serve to reduce information asymmetry and increase trust, but may also lead to a lack of information diversity. Sustainable family business theory (Stafford et al., 2010) explains the positive effects of family capital nevertheless has lower explanatory power of the negative effect of family human capital on duration. Other previous research reported the importance of social networks (Stephens, 2013) and family capital to entrepreneurship (Andersson et al., 2018; Refugees and labor migrants Arcand, 2012).

Although other studies reported positive relation of social capital to startups in Sweden (Backman et al., 2020; Barth and Zalkat, 2020; Eriksson and Rataj, 2019), our main analysis found no apparent effects of ethnic capital in the form of co-ethnics in the nearby area on either category of migrant's likelihood of exit from self-employment. However, in the robustness tests distinguishing between entrepreneurs exiting to unemployment compared to those exiting to paid employment, we found that ethnic capital reduced the likelihood that a refugee entrepreneur would exit business and become unemployed. The potential role of ethnic enclaves in fostering co-ethnics economic success has a long tradition of research in economics, sociology and entrepreneurship both in the USA and in various European nations (Arcand, 2012; Lancee, 2012; Portes, 1995b; Stephens, 2013). Common explanation for the economic advantages for migrant entrepreneurs locating their businesses in an ethnic enclave include access to co-ethnics as customers (Bates, 2011). This is a sizeable effect and could likely depend on co-ethnics being important for local businesses as customers, resources providers, etc. (Barth and Zalkat, 2020; Bates, 2011). As Kloosterman et al. (1999) highlighted in their analysis of immigrant entrepreneurs in the Netherlands, Islamic customers exhibited very high loyalty toward co-ethnic groceries in co-ethnic neighborhoods (Bisignano and El-Anis, 2019; Elo and Dana, 2019). Such customer loyalty and other intangible benefits from locating their business in co-ethnic neighborhoods are likely to facilitate refugee entrepreneurs' potential to stay in business and avoid unemployment, even if their human capital resources are often more limited (Carter and Ram, 2003; Gold, 1988).

Taken together, our findings provide compelling answers to our research question of how kinship-based resources influence refugees and labor migrants' likelihood of remaining in self-employment, opening up new avenues for future research.

First, our study provides empirical and theoretical contributions to research on the success of self-employed migrants by contrasting distinct groups of migrants engaging in self-employment. Labor migrants and refugees both tend to be overrepresented in selfemployment compared to natives, yet there is a paucity of studies on their relative rates of economic disadvantage, the extent to which these disadvantages affect their ability to sustain themselves in self-employment, and whether and how access to family- and kinshipbased resources can affect their chances of self-employment success.

By comparing two large categories of migrants that are often lumped together, our study shows that not only do their relative rates of disadvantage in terms of likelihood of sustaining themselves as self-employed entrepreneurs differ, but also that the different types of kinship-based capital resources mitigate these disadvantages in distinct ways, whereas labor migrants exhibit, on average, longer self-employment duration than do refugees, refugee entrepreneurs have on average larger households and also seem to benefit more from the available financial capital resources in their family. Consequently, the theoretical mechanisms suggested by kinship-based theories seem especially relevant for refugee entrepreneurs, a group of entrepreneurs that often have been lumped together with 
other migrants in extant studies (Portes, 1995a, 1995b; Verver and Koning, 2017). These results moderate prevailing expectations that refugees are homogenously at an economic disadvantage compared to other groups of migrants (Backman et al., 2020; Barth and Zalkat, 2020), and highlight the importance of family members' resources in explaining what makes certain refugee entrepreneurs relatively less at a disadvantage.

Second, this study is to the best of our knowledge among the first to integrate insights from research on the economic embeddedness of migrants in economic sociology from its original US context into the setting of a high-income European Welfare state, where selfemployment and conditions for the success of self-employed migrants is a more recent source of academic research and public policy debate.

We found surprisingly strong effects of all three forms of family members' capital resources on the likelihood of refugee entrepreneurs sustaining themselves longer in selfemployment - however not for labor migrants. These findings show the generality of theories of bounded solidarity and family resource-pooling that originally emerged in studies of ethnic enclaves and migrant businesses in the USA several decades ago, but also that modern studies have to incorporate the heterogeneity of migrants for theoretical testing of such theories. For example, a recent Turkish study found that full integration of refugees into the Turkish local market takes time therefore they "start a business in familiar surroundings within refugee enclaves" (Alrawadieh et al., 2019). Although factors related to self-employment duration among refugee are less often investigated in the literature, our findings provide more precise extensions of the thesis that know-how among refugee entrepreneurs may be related both to access to information and host country-specific human capital obtained via kinship and ethnic linkages (Desai et al., 2020; Andersson et al., 2018). Our paper indicates that to obtain such information and human capital resources, proximity to kin, in particular kin with prior entrepreneurial experience, seem vital.

\section{Implications}

Our paper suggests a series of implications for policymakers and both refugee and labor migrant entrepreneurs. Our theoretical arguments and findings that immigrant financial resources among the family members decrease their probability for exit business motivate considerations of family members of immigrants as important in alleviating the credit constrains that many immigrant entrepreneurs face (Alrawadieh et al., 2019; Malki et al., 2020). This highlights the importance for policymakers to understand the relevance of families for immigrants' owned firms in terms of providers of financial inputs. Our results highlight that refugee entrepreneurship would, on average, be more successful when migration laws allow for families to stay intact (Desai et al., 2020; Klaesson and Öner, 2020). In that families provide valuable support and resources with which refugee entrepreneurs can sustain themselves in self-employment, it is important that families remain intact: variation in migration regulations across countries and over time may influence the extent to which refugees are able to migrate as a family or be forced to migrate on their own. This insight is also of relevance for immigrant entrepreneurs and potential advisors who may shun from considering family links as sources of financial capital (Malki et al., 2020). For many, this may be the best and only option available, at least in the early stages of venturing.

Our findings related to $H 1 c$ also highlight the value of physical proximity to former entrepreneurs in the extended family for immigrant entrepreneurs to be able to run more long-lasting businesses. Physical proximity is essential for sharing valuable knowledge and entrepreneurial experience among family members, which indicates that policymakers should not necessarily shun from arriving immigrants choosing to locate close to their kin in 
the arrival country, despite this potentially leading to segregated communities. Some ethnic groups such as e.g. Somali refugees seem to be less prone to engage in entrepreneurship and also stay shorter in business compared to other ethnic groups. Given the relative rarity of kinship resources available for entrepreneurs from such underrepresented groups in entrepreneurship, they face higher hurdles as nascent immigrant entrepreneurs to establish and sustain themselves as business owners. Here, some involvement in entrepreneurship start-up programs may enhance their businesses longevity (Carling and Gustafson, 1999). Only by facilitating self-reliance and economic success can Western nations facilitate the Refugees and labor migrants economic integration of immigrants, compared to policies incentivizing or enforcing geographic isolation from extended family and other kin.

\section{Limitations and future research}

Our study also comes with limitations, several of which offer avenues for future research. A first limitation is that our measure of human capital is based on educational credentials received in Sweden and credentials self-reported by migrants upon arrival in Sweden. To the extent that refugees and labor migrants had no education prior to arriving in Sweden and chose not to report educational credentials, our measure of human capital - both among individual entrepreneurs (as a control variable) and among family members in the household (our $H 1 b$ ) - is likely to be underestimated. To the extent that this is a random rather than a systematic error, it would not invalidate our inference from $H 1 b$ as any underestimation would render coefficient estimates downwards, not upwards.

A second limitation is that our data do not allow for studying indirect support from family members abroad. Although informal advice and emotional support is less accessible from a distance, financial capital can and is often transferred overseas to and from migrating family members (Finkelstein Shapiro and Mandelman, 2016). Remittances transferred from self-employed refugees and labor migrants in Sweden to family members in other countries would not bias our results, but remittances flowing in the other direction would mean that we have potentially underestimated the level of family financial capital support. However, we see no reason that labor migrant entrepreneurs would receive larger in-remittances than refugee entrepreneurship. On the contrary, most studies suggest that labor migrants are those that most often engage in out-remittances to family members remaining in their home country (Finkelstein Shapiro and Mandelman, 2016). The study of remittances by migrants who become entrepreneurs in the host country is an interesting and expanding phenomenon that offers interesting pathways for future research to study whether entrepreneurship is triggered elsewhere, that is, among re-migrating individuals or their family members (Portes et al., 2002). Kinship-based resource provision could well be integrated in the growing research on "transnational entrepreneurship" which to date has tended to focus on individuals that move across countries to start new businesses (Drori et al., 2009), and not how family disruptions or ethnic networks across national boundaries by lead to exchange of information, support, and resources of relevance in entrepreneurship.

Third, following a long line of research on the relative disadvantages among minority entrepreneurs (Bates, 1999; Joona, 2010), our dependent variable in this study was the likelihood of exiting self-employment. Our robustness tests show that the majority of labor migrants and refugee migrants do in fact exit to unemployment, making this line of inquiry a valid enterprise. However, the robustness tests also showed that when distinguishing between those that exit to paid employment and those that exit to unemployment, the effect of family financial capital differs for these two types of exit routes. Future research could look deeper into the effect of access to financial capital at various stages of entrepreneurship among immigrant entrepreneurs: For example, to what extent are immigrant entrepreneurs 
financially and/or morally "indebted" to family members or other kin by borrowing funds for their businesses, and how would that affect the fate of the firms they start? Can refugee entrepreneurs be financially indebted to others after spending long time fleeing their home country? If refugee entrepreneurs do exit to unemployment, what happens with such debts? Research on the nuanced effects of family- and kinship-based resources available for diverse groups of immigrant entrepreneurs is still at an early stage, and future research would therefore benefit from primary data on, for example, overseas family members, forms of advice and financial help (loans or equity), and whether there could be unwarranted side effects of family members' and kinship-based resource-giving in immigrant businesses (Portes and Sensenbrenner, 1993). Such research could well take advantage of the generic findings we highlight and seek to challenge, extend, or refine those using, e.g. primary network data, surveys, or case study data. How immigrants such as refugee and labor migrants rely differentially on informal support structures such as family and ethnic kin for entrepreneurial endeavors, the processes by which this occurs, and with varying outcomes may lead to a broader research agenda of increasing relevance in the $21^{\text {st }}$ century as people are increasingly uprooted from their home countries, and entrepreneurship is increasingly becoming a global phenomenon.

\section{Notes}

1. In the paper, we therefore use the terms "entrepreneurship" and "self-employment" interchangeably.

2. Ethnic capital is measured as "number of co-ethnics in the local (SAMS) area," see p.15.

3. LISA is the acronym for "Longitudinell integrationsdatabas för Sjukförsäkrings- och Arbetsmarknadsstudier."

4. We are grateful to an anonymous reviewer for suggesting this.

5. Statistics Sweden classifies individuals as full-time self-employed if their occupation is specified as being an entrepreneur either in a sole proprietorship, partnership, or a privately held business and they receive their highest source of income from being an entrepreneur (similar to e.g. Block and Sandner, 2009).

6. SAMS is our proxy for local neighborhoods. There are 9,200 different SAMS areas in Sweden.

\section{References}

Aldrich, H.E. and Cliff, J.E. (2003), "The pervasive effects of family on entrepreneurship: toward a family embeddedness perspective", Journal of Business Venturing, Vol. 18 No. 5, pp. 573-596, doi: 10.1016/S0883-9026(03)00011-9.

Aldrich, H. and Kim, P. (2007), "Small worlds, infinite possibilities? How social networks affect entrepreneurial team formation and search", Strategic Entrepreneurship Journal, Vol. 1 Nos 1/2, pp. 147-165, doi: 10.1002/sej.8.

Aldrich, H. and Waldinger, R. (1990), "Ethnicity and entrepreneurship", Annual Review of Sociology, Vol. 16 No. 1, pp. 111-135, doi: 10.1146/annurev.soc.16.1.111.

Aliaga-Isla, R. and Rialp, A. (2013), "Systematic review of immigrant entrepreneurship literature: previous findings and ways forward", Entrepreneurship and Regional Development, Vol. 25 Nos 9/10, pp. 819-844, doi: 10.1080/08985626.2013.845694.

Alrawadieh, Z., Karayilan, E. and Cetin, G. (2019), "Understanding the challenges of refugee entrepreneurship in tourism and hospitality", The Service Industries Journal, Vol. 39 Nos 9/10, pp. 717-740, doi: 10.1080/02642069.2018.1440550. 
Andersson, H. (2020), "Ethnic enclaves, self-employment, and the economic performance of refugees: evidence from a Swedish dispersal policy", International Migration Review, doi: 10.1177/ 0197918320912195.

Andersson, L. and Hammarstedt, M. (2015), "Ethnic enclaves, networks and self-employment among middle eastern immigrants in Sweden”, International Migration, Vol. 53 No. 6, doi: 10.1111/ j.1468-2435.2011.00714.x.

Andersson, M., Larsson, J.P. and Öner, Ö. (2020), "Ethnic enclaves and self-employment among Middle Eastern immigrants in Sweden: ethnic capital or enclave size?", Regional Studies, pp. 1-15, doi: 10.1080/00343404.00342020.01839638.

Andersson, R., Musterd, S. and Galster, G. (2018), "Port-of-entry neighborhood and its effects on the economic success of refugees in Sweden”, International Migration Review, Vol. 53 No. 3, pp. 1-35, doi: $10.1177 / 0197918318781785$.

Arcand, S. (2012), "Transmission of entrepreneurial spirit from first to second generation ethnic minorities in montreal: opening paths for further researches", Journal of Enterprising Communities: People and Places in the Global Economy, Vol. 6 No. 1, pp. 39-56, doi: 10.1108/ 17506201211210993.

Baccari-Jamoussi, E., Maâlaoui, A., and Leloarne-Lemaire, S. (2017), "The impact of family structure, marital status and the parental model on the business creation process among young tunisian entrepreneurs", In Ratten, V., Ramadani, V., Dana, L.-P., Hisrich, R.D. and Ferreira, J. (Eds), Gender and Family Entrepreneurship, Routledge, pp. 142-170. 10.1017/ CBO9781107415324.004.

Backman, M., Lopez, E. and Rowe, F. (2020), "The occupational trajectories and outcomes of forced migrants in Sweden", Entrepreneurship, Employment or Persistent Inactivity? Small Business Economics, doi: 10.1007/s11187-019-00312-z.

Barth, H. and Zalkat, G. (2020), "Immigrant entrepreneurship in Sweden: the liability of newness", Sustainability, Vol. 12 No. 16, pp. 1-17.

Basu, A. and Goswami, A. (1999), "South Asian entrepreneurship in great Britain: factors influencing growth", International Journal of Entrepreneurial Behavior and Research, Vol. 5 No. 5, pp. 251-275, doi: 10.1108/13552559910300381.

Bates, T. (1990), "Entreperneur human capital inputs and small business logevity", The Review of Economics and Statistics, Vol. 72 No. 4, pp. 551-559.

Bates, T. (1997), "Financing small business creation: the case of Chinese and Korean immigrant entrepreneurs", Journal of Business Venturing, Vol. 12 No. 2, pp. 109-124, doi: 10.1016/S08839026(96)00054-7.

Bates, T. (1999), "Exiting self-employment: an analysis of Asian immigrant-owned small businesses", Small Business Economics, Vol. 13 No. 3, pp. 171-183, doi: 10.1023/A:1008110421831.

Bates, T. (2011), "Minority entrepreneurship", Foundations and Trends® in Entrepreneurship, Vol. 7 Nos 3/4, pp. 151-311.

Bates, T., Bradford, W.D. and Seamans, R. (2017), "Minority entrepreneurship in twenty-first century America”, Small Business Economics, Vol. 50 No. 3, pp. 1-13, doi: 10.1007/s11187017-9883-5.

Baycan, T., Sahin, M. and Nijkamp, P. (2012), "The urban growth potential of second-generation migrant entrepreneurs: a sectoral study on Amsterdam", International Business Review, Vol. 21 No. 6, pp. 971-986, doi: 10.1016/j.ibusrev.2011.11.005.

Berg, L. and Spehar, A. (2013), "Swimming against the tide: why Sweden supports increased labour mobility within and from outside the EU", Policy Studies, Vol. 34 No. 2, pp. 142-161, doi: 10.1080/ 01442872.2013 .767585$.

Bhugra, D. (2004), "Migration and mental health", Acta Psychiatrica Scandinavica, Vol. 109 No. 4, pp. 243-258. 
Bird, M. and Wennberg, K. (2016), "Why family matters: the impact of family resources on immigrant entrepreneurs' exit from entrepreneurship”, Journal of Business Venturing, Vol. 31 No. 6, pp. 687-704, doi: 10.1016/j.jbusvent.2016.09.002.

Bisignano, A.P. and El-Anis, I. (2019), "Making sense of mixed-embeddedness in migrant informal enterprising: the role of community and capital", International Journal of Entrepreneurial Behavior and Research, Vol. 25 No. 5, pp. 974-995, doi: 10.1108/IJEBR-03-2018-0114.

Block, J. and Sandner, P. (2009), "Necessity and opportunity entrepreneurs and their duration in selfemployment: evidence from German micro data", Journal of Industry, Competition and Trade, Vol. 9 No. 2, pp. 117-137, doi: 10.1007/s10842-007-0029-3.

Braunerhjelm, P. and Carlsson, B. (1999), "Industry clusters in Ohio and Sweden, 1975-1995", Small Business Economics, Vol. 12 No. 4, pp. 279-293, doi: 10.1023/A:1008079014165.

Caputo, R.K. and Dolinsky, A. (1998), “Women's choice to pursue self-employment: the role of financial and human capital of household members", Journal of Small Business Management, Vol. 36 No. 3, pp. 8-17.

Carling, K. and Gustafson, L. (1999), Self-Employment Grants vs. subsidized Employment: Is There a Difference in the Re-Unemployment Risk?, IFAU: Swedish Institute for Labor Market Policy Evaluation.

Carter, S. and Ram, M. (2003), "Reassessing portfolio”, Small Business Economics, Vol. 21 No. 4, pp. 371-380.

Castles, S., Haas, H.D., and Miller, M. (2013), The Age of Migration: International Population Movements in the Modern World, Palgrave Macmillan.

Chiswick, B.R., Lee, Y.L. and Miller, P.W. (2005), "A longitudinal analysis of immigrant occupational mobility: a test of the immigrant Assimihtion hypothesis", International Migration Review, Vol. 39 No. 2, pp. 332-353.

Collier, P. (2013), Exodus: How Migration is Changing Our World, Oxford University Press.

Cooper, A.C., Gimeno-Gascon, F.J. and Woo, C.Y. (1994), "Initial human and financial capital as predictors of new venture performance", Journal of Business Venturing, Vol. 9 No. 5, pp. 371-395, doi: 10.1016/0883-9026(94)90013-2.

Dahl, M.S. and Sorenson, O. (2009), "The embedded entrepreneur", European Management Review, Vol. 6 No. 3, pp. 172-181.

Dana, L.-P. (2007), Handbook of Research on Ethnic Minority Entrepreneurship: A co-Evolutionary View on Resource Management, Edward Elgar Publishing.

Davidsson, P. and Honig, B. (2003), "The role of social and human capital among nascent entrepreneurs", Journal of Business Venturing, Vol. 18 No. 3, pp. 301-331, doi: 10.1016/S0883-9026(02)00097-6.

Desai, S., Naudé, W. and Stel, N. (2020), "Refugee entrepreneurship: context and directions for future research", Small Business Economics, doi: 10.1007/s11187-019-00310-1.

Drori, I., Honig, B. and Wright, M. (2009), “Transnational entrepreneurship: an emergent field of study”, Entrepreneurship Theory and Practice, Vol. 44 No. 0, pp. 1001-1023.

Dustmann, C. (1999), "Temporary migration, human capital, and language fluency of migrants", Scandinavian Journal of Economics, Vol. 101 No. 2, pp. 297-314, doi: 10.1111/1467-9442.00158.

Duvander, A.Z.E. (2001), "Do country-specific skills lead to improved labor market positions? An analysis of unemployment and labor market returns to education among immigrants in Sweden”, Work and Occupations, Vol. 28 No. 2, pp. 210-233, doi: 10.1177/0730888401028002005.

Edmark, K. and Gordon, R.H. (2013), "The choice of organizational form by closely-held firms in Sweden: tax versus non-tax determinants", Industrial and Corporate Change, Vol. 22 No. 1, pp. 219-243, doi: 10.1093/icc/dts045.

Efendic, N., Andersson, F.W. and Wennberg, K. (2016), "Growth in first- and second-generation immigrant firms in Sweden", International Small Business Journal: Researching Entrepreneurship, Vol. 34 No. 8, pp. 1028-1052, doi: 10.1177/0266242615612533. 
Elo, M. and Dana, L.-P. (2019), "Embeddedness and entrepreneurial traditions: entrepreneurship of Bukharian Jews in diaspora”, Journal of Family Business Management, doi: 10.1108/JFBM-032019-0016.

Emilsson, H. (2014), "Who gets in and why? The Swedish experience with demand driven labour migration - some preliminary results", Nordic Journal of Migration Research, Vol. 4 No. 3, pp. 134-143, doi: 10.2478/njmr-2014-0017.

Eriksson, R. and Rataj, M. (2019), "The geography of starts-ups in Sweden. The role of human capital, social capital and agglomeration", Entrepreneurship and Regional Development, Vol. 31 Nos 9/10, pp. 735-754, doi: 10.1080/08985626.2019.1565420.

Ertug, G., Kotha, R. and Hedstrom, P. (2020), "Kin ties and the performance of new firms: a structural approach", Academy of Management Journal, Vol. 63 No. 6, doi: 10.5465/amj.2017.1218.

Esping-Andersen, G. (1990), The Three Worlds of Welfare Capitalism, Princeton University Press.

Estrin, S., Mickiewicz, T. and Stephan, U. (2016), "Human capital in social and commercial entrepreneurship”, Journal of Business Venturing, Vol. 31 No. 4, pp. 449-467, doi: 10.1016/j. jbusvent.2016.05.003.

Evans, D.S. and Leighton, L.S. (1989), "Some empirical aspects of entrepreneurship published by: American economic association stable", The American Economic Review, Vol. 79 No. 3, pp. 519-535, available at: www.jstor.org/stable/1806861

Evansluong, Q. and Pasillas, M.R. (2017), “The role of family social capital in immigrants' entrepreneurial opportunity creation processes", International Journal of Entrepreneurship and Small Business.

Finkelstein Shapiro, A. and Mandelman, F.S. (2016), "Remittances, entrepreneurship, and employment dynamics over the business cycle", Journal of International Economics, Vol. 103, pp. 184-199, doi: 10.1016/j.jinteco.2016.10.001.

Frederiksen, L., Wennberg, K. and Balachandran, C. (2016), "Mobility and entrepreneurship: evaluating the scope of theories of entrepreneurship", Entrepreneurship Theory and Practice, Vol. 40 No. 2, pp. 359-380, doi: 10.1111/etap.12223.

Godesiabois, J. (2005), "Network analysis in an international entrepreneurial environment", In Advances in Entrepreneurship, Firm Emergence and Growth, Vol. 8, pp. 137-164, doi: 10.1016/S1074-7540 (05)08006-2.

Gold, S.J. (1988), "Refugees and small business: the case of soviet Jews and Vietnamese", Ethnic and Racial Studies, Vol. 11 No. 4, pp. 411-438, doi: 10.1080/01419870.1988.9993613.

Granovetter, M. (1985), "Economic action and social structure: the problem of embeddedness", American Journal of Sociology, Vol. 91 No. 3, pp. 481-510.

Granovetter, M. (1998), "The economic sociology of firms and entrepreneurs", in The Economic Sociology of Immigration: Essays on Networks, Ethnicity, and Entrepreneurship, Russell Sage Foundation, pp. 128-165.

Hagelund, A. (2020), "After the refugee crisis: public discourse and policy change in Denmark", Comparative Migration Studies, Vol. 8 No. 1, pp. 1-17.

Hammarstedt, M. (2001), "Disposable income differences between immigrants and natives in Sweden", International Journal of Social Welfare, Vol. 10 No. 2, pp. 117-126.

Hammarstedt, M. (2003), "Income from work among immigrants in Sweden”, Review of Income and Wealth, Vol. 49 No. 2, pp. 185-203.

Hammarstedt, M. (2004), "Self-employment among immigrants in Sweden - an analysis of intragroup differences", Small Business Economics, Vol. 23 No. 2, pp. 115-126, doi: 10.1023/B: SBEJ.0000027664.58874.62.

Heilbrunn, S. and Kushnirovich, N. (2007), "Immigrant and indigenous enterprises: similarities and differences", International Journal of Business Performance Management, Vol. 9 No. 3, pp. 344-361, doi: 10.1504/IJBPM.2007.013312. 
Hjerm, M. (2004), "Immigrant entrepreneurship in the Swedish welfare state", Sociology, Vol. 38 No. 4, pp. 739-756, doi: 10.1177/0038038504045862.

IOM (2018), "World Migration Report 2018”. International Organisation for Migration.

Joona, P.A. (2010), "Exits from self-employment: is there a native-immigrant difference in Sweden?", International Migration Review, Vol. 44 No. 3, pp. 539-559, doi: 10.1111/j.1747-7379.2010.00817.x.

Kautonen, T., Down, S. and Minniti, M. (2014), "Ageing and entrepreneurial preferences", Small Business Economics, Vol. 42 No. 3, pp. 579-594, doi: 10.1007/s11187-013-9489-5.

Kim, P.H., Longest, K.C. and Aldrich, H.E. (2013), "Can you lend me a hand? Task-role alignment of social support for aspiring business owners”, Work and Occupations, Vol. 40 No. 3, pp. 213-249, doi: 10.1177/0730888413481365.

Klaesson, J. and Öner, Ö. (2020), Ethnic Enclaves and Segregation - Self-Employment and Employment Patterns among Forced Migrants, Small Business Economics.

Kloosterman, R. (2000), "Immigrant entrepreneurship and the institutional context: a theoretical exploration”, In Rath, J. (Ed.), Immigrant Businesses: The Economic, Political and Social Environment, Macmilian, pp. 90-106.

Kloosterman, R. (2010), "Matching opportunities with resources: a framework for analysing (migrant) entrepreneurship from a mixed embeddedness perspective", Entrepreneurship and Regional Development, Vol. 22 No. 1, pp. 25-45, doi: 10.1080/08985620903220488.

Kloosterman, R., van der Leun, J. and Rath, J. (1999), "Mixed embeddedness: (in)formal economic activities and immigrant businesses in The Netherlands", International Journal of Urban and Regional Research, Vol. 23 No. 2, pp. 252-267, doi: 10.1111/1468-2427.00194.

Kossoudji, S.A. (1989), "Immigrant worker assimilation: is it a labor market phenomenon?", The Journal of Human Resources, Vol. 24 No. 3, p. 494, doi: 10.2307/145825.

Kushnirovich, N., Heilbrunn, S. and Davidovich, L. (2017), "Diversity of entrepreneurial perceptions: immigrants vs native population", European Management Review, Vol. 15 No. 3.

Kwon, S.W., Heflin, C. and Ruef, M. (2013), "Community social capital and entrepreneurship”, American Sociological Review, Vol. 78 No. 6, pp. 980-1008, doi: 10.1177/0003122413506440.

Lancaster, T. (1992), The Econometric Analysis of Transition Data, Cambridge University Press. $10.2307 / 2554893$.

Lancee, B. (2012), "Immigrant performance in the labour market".

Levin, I. and Trost, J. (1992), "Understanding the concept of family", Family Relations, Vol. 41 No. 3, pp. 348-351.

Light, I. and Rosenstein, C. (1995), "Expanding the interaction theory of entrepreneurship", In Alejandro, P. (Ed.), The Economic Sociology of Immigration: Essays on Networks, Ethnicity, and Entrepreneurship, Russell Sage Foundation, pp. 166-212.

Malki, B., Uman, T. and Pittino, D. (2020), "The entrepreneurial financing of the immigrant entrepreneurs: a literature review”, Small Business Economics, pp. 1-29, doi: 10.1007/s11187-020-00444-7.

Marchand, K. and Siegel, M. (2015), "World migration report”, Immigrant Entrepreneurship in Cities Background Paper (Issue December 2014, Vol. 2015).

Ndofor, H.A. and Priem, R.L. (2011), "Immigrant entrepreneurs, the ethnic enclave strategy, and venture performance", Journal of Management, Vol. 37 No. 3, pp. 790-818, doi: 10.1177/ 0149206309345020 .

Nziramasanga, M. and Lee, M. (2001), "Duration of self-employment in developing countries: evidence from small enterprises in Zimbabwe”, Small Business Economics, Vol. 17 No. 4, pp. 239-253, doi: 10.1023/A:1012209408597.

Ohlsson, H., Bevelander, P. and Broome, P. (2012), "Self-employment of immigrants and natives in Sweden - a multilevel analysis", Entrepreneurship and Regional Development, Vol. 24 Nos 5/6, pp. 405-423. 
Özcan, B. (2011), "Only the lonely? The influence of the spouse on the transition to self-employment", Small Business Economics, Vol. 37 No. 4, pp. 465-492, doi: 10.1007/s11187-011-9376-x.

Portes, A. (1995a), "Economic sociology and the sociology of immigration: a conceptual overview", In Portes, A. (Ed.), The Economic Sociology of Immigration. Essays on Networks, Ethnicity and Entrepreneurship, Russell Sage Foundation, pp. 1-41.

Portes, A. (1995b), "Economic sociology and the sociology of immigration: a conceptual overview", In Portes, A. (Ed.), The Economic Sociology of Immigration. Essays on Networks, Ethnicity and Entrepreneurship, Russell Sage Foundation, p. 324.

Portes, A. and Sensenbrenner, J. (1993), "Embeddedness and immigration: notes on the social determinants of economic action”, American Journal of Sociology, Vol. 98 No. 6, pp. 1320-1350.

Portes, A. and Zhou, M. (1993), "The new second generation: segmented assimilation and ITs variants", The Annals of the American Academy of Political and Social Science, Vol. 530 No. 1, pp. 74-96, doi: 10.1016/S0363-8111(97)90017-5.

Portes, A., Haller, W.J. and Guarnizo, L.E. (2002), "Transnational entrepreneurs: an alternative form of immigrant economic", American Sociological Review, Vol. 67 No. 2, pp. 278-298.

Rath, J. and Kloosterman, R. (2001), "Immigrant entrepreneurs in advanced economies: mixed embeddedness further explored", Journal of Ethnic and Migration Studies, Vol. 27 No. 2, pp. 189-201, doi: 10.1080/13691830123940.

Ratten, V., Dana, L.-P. and Ramadani, V. (2017), "Women entrepreneurship in family business", In Ratten, V., Dana, L.-P. and Ramadani, V. (Eds), Women Entrepreneurship in Family Business, Routledge, pp. 1-15.

Richmond, A.H. (1988), "Sociologicol theories of I nternotionol migrotion: the cose of refugeesl", Current Sociology, Vol. 36 No. 2, pp. 7-25.

Ruef, M. (2010), The Entrepreneurial Group: Social Identities, Relations, and Collective Action, Princeton University Press. 10.1017/CBO9781107415324.004.

Sandberg, S., Immonen, R. and Kok, S. (2019a), "Refugee entrepreneurship: taking a social network view on immigrants with refugee backgrounds starting transnational businesses in Sweden", International Journal of Entrepreneurship and Small Business, Vol. 36 Nos 1/2, pp. 216-241, doi: 10.1504/ijesb.2019.096967.

Sandberg, S., Immonen, R. and Kok, S. (2019b), "Refugee entrepreneurship: taking a social network view on immigrants with refugee backgrounds starting transnational businesses in Sweden", International Journal of Entrepreneurship and Small Business, Vol. 36 Nos 1/2, pp. 216-241.

Sanders, J.M. and Nee, V. (1996), "Immigrant self-employment: the family as social capital and the value of human capital", American Sociological Review, Vol. 61 No. 2, pp. 231-249.

Santamaria-Alvarez, S.M. and Ś liwa, M. (2016), "Transnational entrepreneurship in emerging markets: the Colombian case", Journal of Enterprising Communities: People and Places in the Global Economy, Vol. 10 No. 2, pp. 203-223, doi: 10.1108/JEC-10-2013-0030.

Schutjens, V., de Vries, N. and Risselada, A. (2017), "Geographies of growth: innovations, networks and collaborations”, In Karlsson, C., Andersson, M. and Bjerke, L. (Eds), Geographies of Growth: Innovations, Networks and Collaborations, Edward Elgar Publishing, p. 480, 10.4337/ 9781785360602.

Shane, S. (2003), A General Theory of Entrepreneurship: The Individual-Opportunity Nexus, Edward Elgar.

Shepherd, D.A., Philippe, F. and Wincent, J. (2020), "How to circumvent adversity? Refugeeentrepreneurs' resilience in the face of substantial and persistent adversity", Journal of Business Venturing, Vol. 35 No. 4, pp. 1-26, doi: 10.1016/j.jbusvent.2019.06.001.

Stafford, K., Bhargava, V., Danes, S.M., Haynes, G. and Brewton, K.E. (2010), "Factors associated with long-term survival of family businesses: duration analysis", Journal of Family and Economic Issues, Vol. 31 No. 4, pp. 442-457, doi: 10.1007/s10834-010-9232-1. 
Stephens, S. (2013), "Building an entrepreneurial network: the experiences of immigrant entrepreneurs", Journal of Enterprising Communities: People and Places in the Global Economy, Vol. 7 No. 3, pp. 233-244, doi: 10.1108/JEC-12-2011-0026.

Taylor, J.E. (1999), "The new economics of labour migration and the role of remittances in the migration process", International Migration, Vol. 37 No. 1, pp. 63-88.

Ucbasaran, D., Westhead, P. and Wright, M. (2009), "The extent and nature of opportunity identification by experienced entrepreneurs", Journal of Business Venturing, Vol. 24 No. 2, pp. 99-115, doi: 10.1016/j.jbusvent.2008.01.008.

Unger, J.M., Rauch, A., Frese, M. and Rosenbusch, N. (2011), "Human capital and entrepreneurial success: a meta-analytical review”, Journal of Business Venturing, Vol. 26 No. 3, pp. 341-358, doi: 10.1016/j.jbusvent.2009.09.004.

Van Praag, C.M. (2003), "Business survival and success of young small business owners", Small Business Economics, Vol. 21 No. 1, pp. 1-17, doi: 10.1023/A:1024453200297.

Verver, M. and Koning, J. (2017), "Toward a kinship perspective on entrepreneurship", Entrepreneurship Theory and Practice, Vol. 42 No. 4, pp. 631-666, doi: 10.1177/ 1042258718783431.

Welter, F., Baker, T., Audretsch, D.B. and Gartner, W.B. (2017), "Everyday entrepreneurship - a call for entrepreneurship research to", Entrepreneurship Theory and Practice, Vol. 41 No. 3, pp. 311-321, doi: 10.1111/etap.12258.

Wennberg, K. (2009), Entrepreneurial Exit, Stockholm School of Economics.

\section{Corresponding author}

Aliaksei Kazlou can be contacted at: aliaksei.kazlou@liu.se 
JEC

42

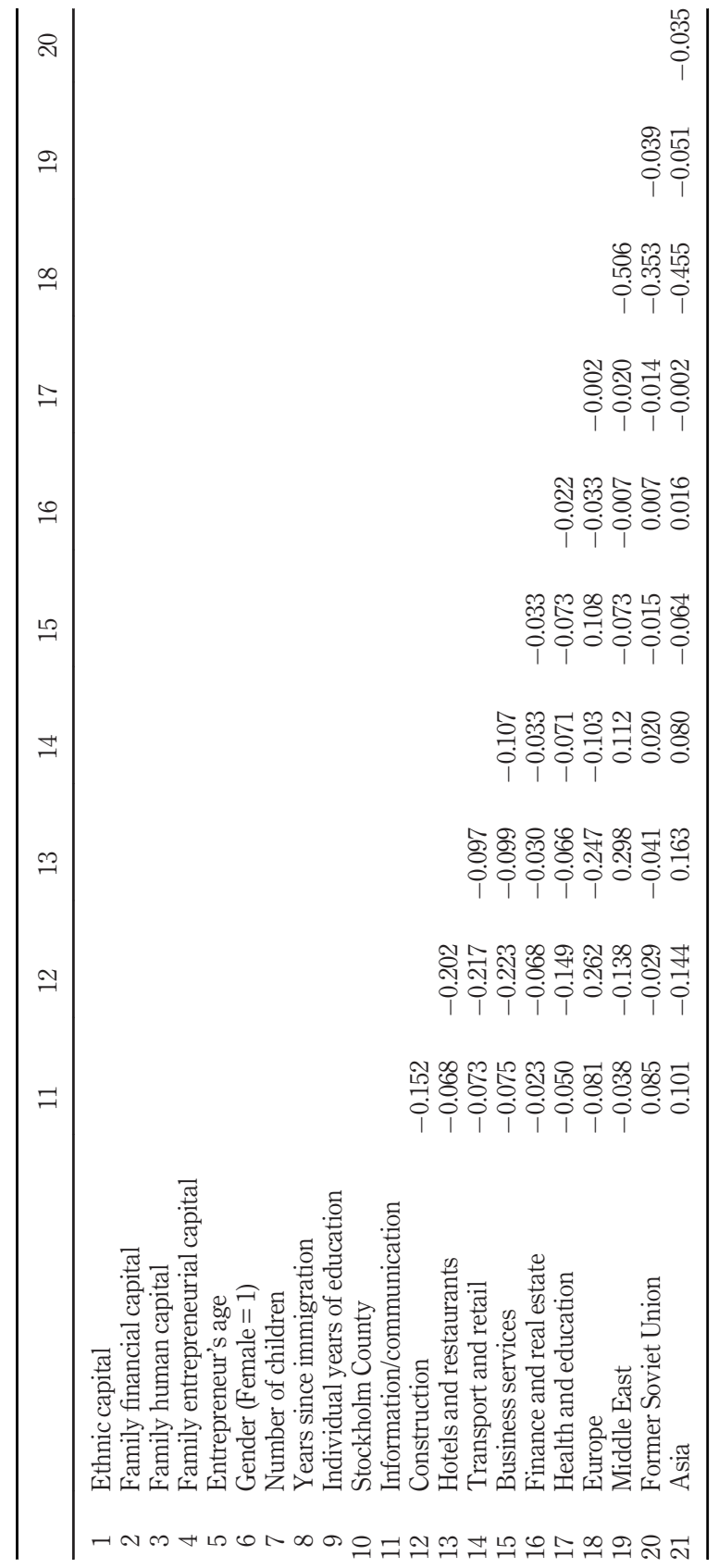

Table A1. 


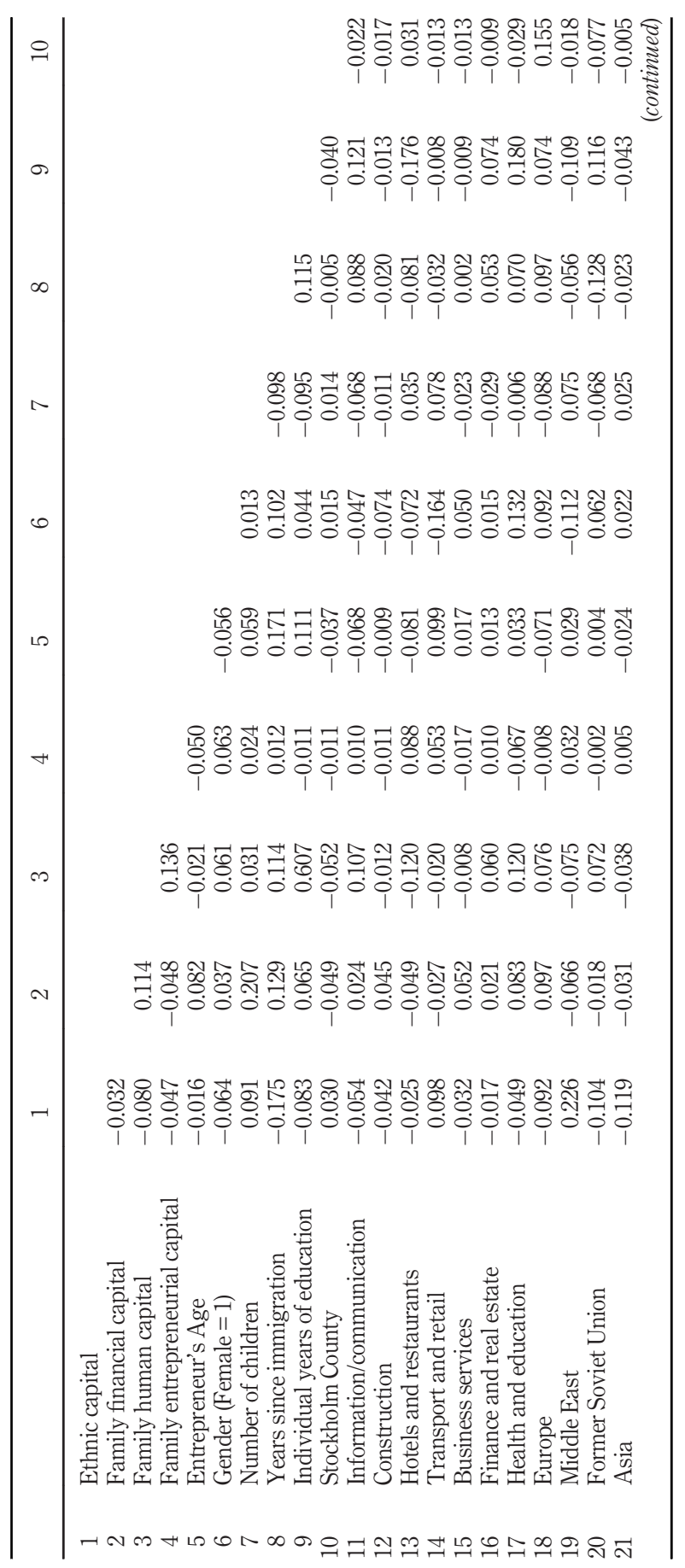

Refugees and labor migrants

43

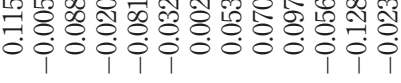

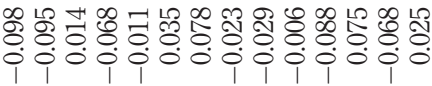

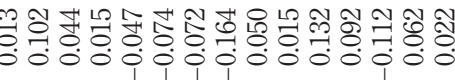

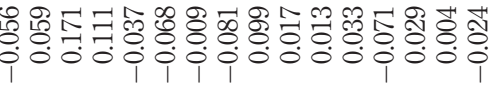

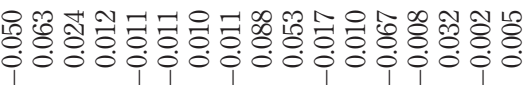

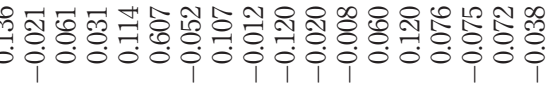

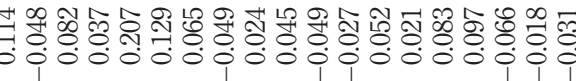

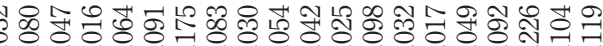

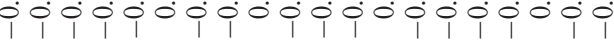

Table A2. Correlation matrix refugees $(N=10,519)$ 
JEC
17,1

44

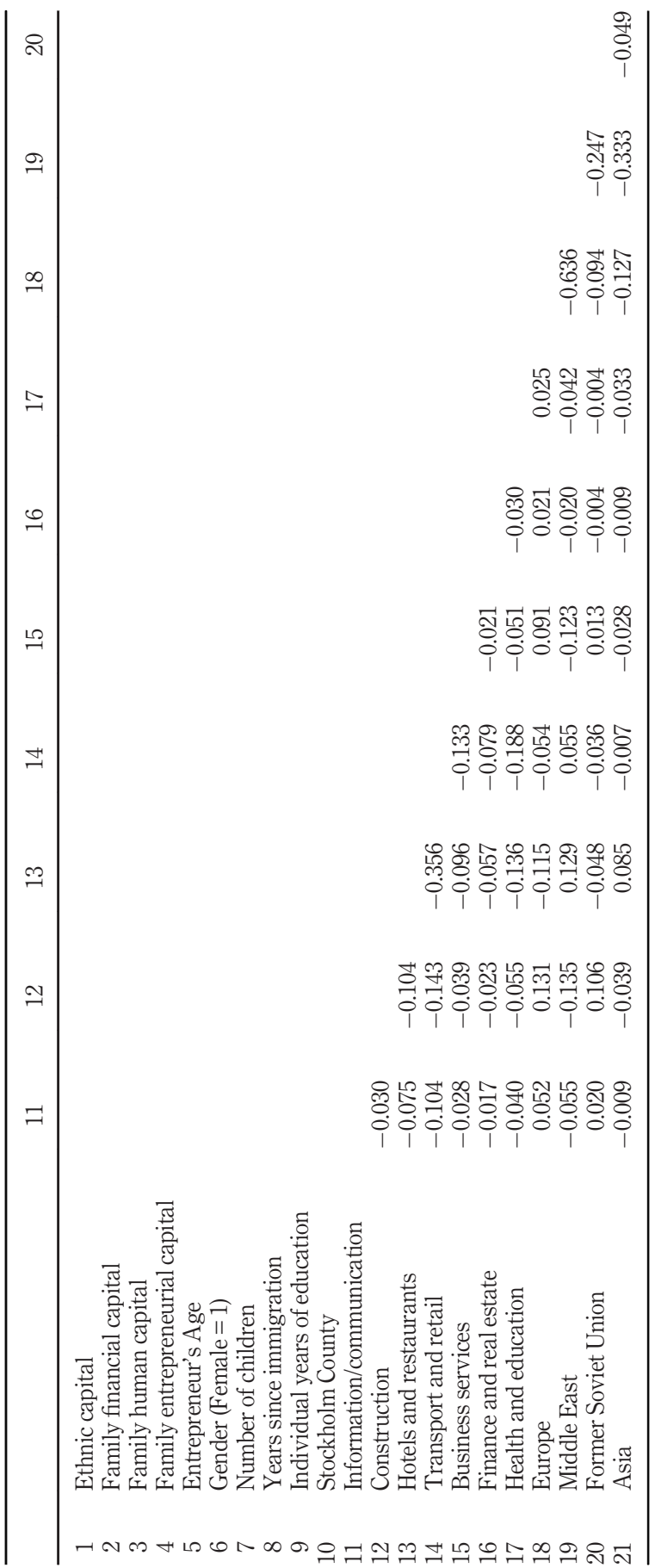

Table A2. 


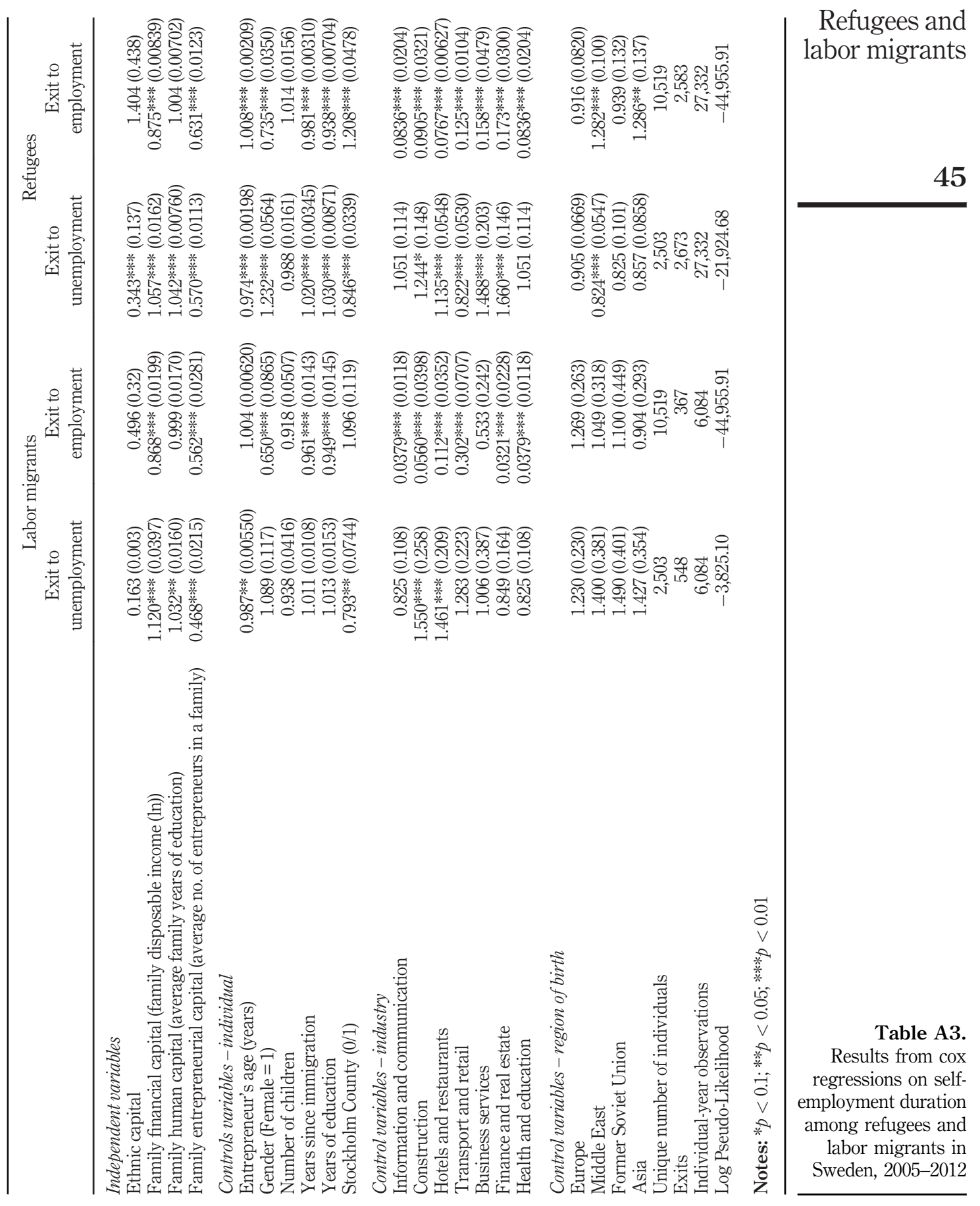

